\title{
Precipitation and Air Temperature Impact on Seasonal Variations of Groundwater Levels
}

\author{
Ilva Vitola ${ }^{1}$, Valdis Vircavs ${ }^{2}$, Kaspars Abramenko $^{3}$, Didzis Lauva ${ }^{4}$, Arturs Veinbergs $^{5}$, \\ ${ }^{1-5}$ Latvia University of Agriculture, Department of Environmental Engineering and Water Management
}

\begin{abstract}
The aim of this study is to clarify seasonal effects of precipitation and temperature on groundwater level changes in monitoring stations of the Latvia University of Agriculture - Mellupīte, Bērze and Auce. Groundwater regime and level fluctuations depend on climatic conditions such as precipitation intensity, evapotranspiration, surface runoff and drainage, as well as other hydrological factors. The relationship between precipitation, air temperature and groundwater level fluctuations could also lead and give different perspective of possible changes in groundwater quality. Using mathematical statistics and graphic-analytic methods it is concluded that autumn and winter precipitation has the dominant impact on groundwater level fluctuations, whereas spring and summer season fluctuations are more dependent on the air temperature.
\end{abstract}

Keywords - air temperature, groundwater level, precipitation intensity, seasonal variations

\section{INTRODUCTION}

Groundwater is one of the most important Latvian natural assets. Shallow groundwater is the top layer of groundwater, which is generally situated in the Quaternary deposits above layers with low permeability, for example, clay layers. Investigations of the relationships between the amount of precipitation, air temperature and variations in the level of groundwater are necessary to facilitate the evaluation of the impact of variations in the level of groundwater on the water quality. It has been proven, utilising various climate models, that, with the increase of the air temperature in the future, the levels of groundwater could increase also during the winter [1]. High levels of groundwater could possibly accelerate the overflow of biogenic substances in the soil massif into groundwater, as well as into the surface water ecosystems. Increased leaching of biogenic elements (predominantly, nitrogen and phosphorus compounds) from the soil is associated with the winter season, when there is no vegetation that consume plant nutrients [2]. The investigation of relationships between the levels of groundwater and meteorological data are also important in order to adjust and improve the model of the balance and regime of groundwater model METUL [3].

As groundwater is the first permanent groundwater aquifer (starting from the earth surface), while groundwater is involved in the single water circulation in nature, groundwater possesses the features of renewable water resources. The groundwater regime and, in particular, that of groundwater and fluctuations of its levels have climatic character in Latvia. Fluctuations of the levels of unconfined groundwater depend on the climatic conditions, such as rainfall intensity and quantity, air temperature, cumulative evaporation or evapotranspiration, surface run-off, as well as on other hydrological, hydrometeorological and relief factors [4], [5] and [6]. Changes in the levels of unconfined groundwater (thus an increase or decrease of the groundwater resources) are seasonal during the year - the level increases during the spring and autumn, and decreases during the winter and, in particular, during the summer [7].

Most of groundwater is formed by the infiltration of precipitation or other surface water (from water bodies and watercourses). Its formation occurs during the time when the amount of precipitation is greater than evapotranspiration. Two stages must be singled out in the process of the formation of groundwater from the precipitation water: the first one is the penetration of the precipitation water into the soil (infiltration), while, during the second stage, after the saturation of the soil with water, its influx (percolation) into the groundwater aquifer starts [7].

The regime of groundwater levels depends mostly on the amount of atmospheric precipitation, air temperature, lithological composition of rocks and degree of the drainage capacity of the area [8].

The purpose of this study is to determine the seasonal impact of precipitation and air temperature on the variations in groundwater levels at the existing monitoring stations that are supervised by the Latvia Agricultural University Mellupīte, Bērze and Auce.

\section{CHARACTERISTICS OF THE STUDY AREA}

Data of the observations of groundwater levels from the three existing monitoring stations that are supervised by the Latvia University of Agriculture (LLU) have been used in the study - Mellupīte (Zaña Parish, Saldus County), Bērze (Jaunbērze Parish, Dobele County) and Auce (Lielauce Parish, Auce County) (Fig. 1).

12 groundwater level monitoring wells have been drilled in the above-mentioned areas -4 wells in Auce, 5 wells in Bērze and 3 wells in Mellupite; measurements of the groundwater level are made automatically using loggers placed in the wells (Geolog Micro). The loggers automatically read the levels of groundwater $(\mathrm{mm})$ and the water temperature (0) once every hour and calculate the average measurement for 24 hours. 


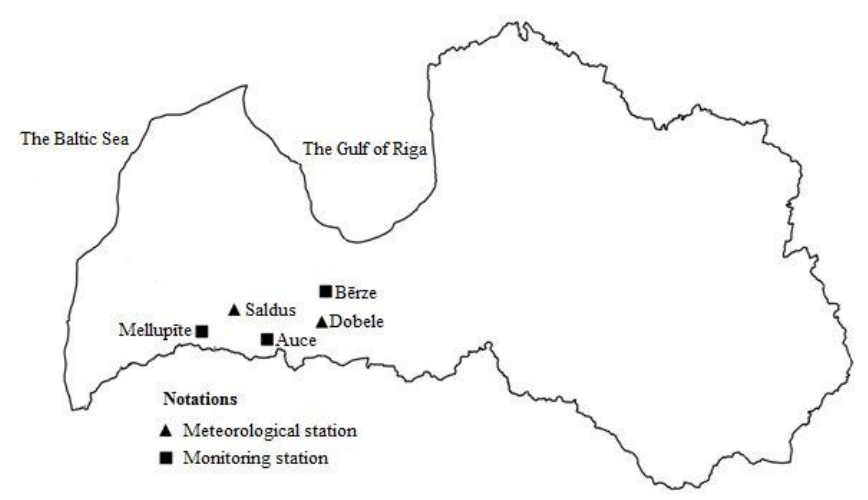

Fig. 1. Meteorological stations and monitoring stations of LLU

The monitoring stations are situated in the areas with different physical-geographic conditions (the main parameters characterizing the area are summarized in Table I), so meteorological data (daily amount of precipitation and air temperature) were obtained using the observations from the Dobele and Saldus meteorological stations.
Respectively, the data from the Dobele meteorological station have been used for the analysis of the levels of unconfined groundwater from the Bērze monitoring station, while the data from the Saldus meteorological station have been used for the analysis of the levels of unconfined groundwater from the Auce and Mellupite monitoring stations (Fig. 1).

Three monitoring wells from each monitoring station have been selected for analysis: Mellupìte - MG1, MG2 and MG3; Bērze - BG2, BG3 and BG4; Auce - AG1, AG2 and AG3. Each of those wells is characterised in Table II. Nine soil sampling drillholes have been drilled in the territories of the monitoring stations - 5 boreholes in Auce, 1 borehole in Bērze and 3 boreholes in Mellupite, with the purpose of obtaining soil samples for the grain-size analysis and determination of the hydraulic conductivity. The data obtained from the boreholes are summarised in Table II.

TABLE I

CHARACTERISTICS OF MONITORING STATIONS

\begin{tabular}{|c|c|c|c|}
\hline & \multicolumn{3}{|c|}{ Monitoring station } \\
\hline & Auce & Bērze & Mellupīte \\
\hline Location & $\begin{array}{l}\text { Auce County, } \\
\text { Lielauce Parish }\end{array}$ & $\begin{array}{l}\text { Dobele County, } \\
\text { Jaunberze parish }\end{array}$ & $\begin{array}{l}\text { Saldus county, } \\
\text { Zana parish }\end{array}$ \\
\hline The average annual air temperature * & $+7.29^{0}$ & $+8.08^{0}$ & $+7.02^{0}$ \\
\hline Month with the lowest average temperature * & February $\left(-3.9^{0}\right)$ & February $\left(-3.3^{0}\right)$ & February $\left(-3.37^{0}\right)$ \\
\hline Month with the highest average temperature * & July $\left(+16.8^{0}\right)$ & August $\left(+17.8^{0}\right)$ & July $\left(+16.79^{0}\right)$ \\
\hline The average annual amount of precipitation * & $762 \mathrm{~mm}$ & $566 \mathrm{~mm}$ & $767 \mathrm{~mm}$ \\
\hline Month with least average amount of precipitation * & February $(45 \mathrm{~mm})$ & February $(32 \mathrm{~mm})$ & February $(44 \mathrm{~mm})$ \\
\hline Month with most average amount of precipitation * & July $(110 \mathrm{~mm})$ & July (76 mm) & July (107 mm) \\
\hline
\end{tabular}

TABLE II

THE CHARACTERISTICS OF BOREHOLES USED IN THE STUDY

\begin{tabular}{|c|c|c|c|c|c|c|c|}
\hline $\begin{array}{c}\text { Number of the } \\
\text { borehole }\end{array}$ & $\begin{array}{l}\text { Depth of the } \\
\text { borehole, } m\end{array}$ & $\begin{array}{c}\text { Soil } \\
\text { sampling } \\
\text { depth, } \mathbf{m}\end{array}$ & $\begin{array}{l}\text { Sand, } \\
\%\end{array}$ & $\begin{array}{l}\text { Silt, } \\
\%\end{array}$ & $\begin{array}{c}\text { Clay, } \\
\%\end{array}$ & $\begin{array}{l}\text { Filtration coefficient in } \\
\text { territory of the } \\
\text { monitoring station, } \mathrm{m} / \mathrm{d}\end{array}$ & $\begin{array}{l}\text { The average groundwater } \\
\text { depth below land surface, } \\
\text { cm }\end{array}$ \\
\hline \multicolumn{8}{|c|}{ Auce } \\
\hline AG1 & 6.00 & - & - & - & - & \multirow{15}{*}{7.46} & 72.60 \\
\hline AG2 & 6.00 & - & - & - & - & & 141.30 \\
\hline AG3 & 11.00 & - & - & - & - & & 77.38 \\
\hline \multirow{3}{*}{ AP1* } & \multirow{3}{*}{1.10} & $0.00-0.20$ & 92.1 & 7.1 & 0.8 & & \multirow{3}{*}{-} \\
\hline & & $0.20-0.65$ & 82.5 & 15.4 & 2.1 & & \\
\hline & & $0.65-1.10$ & 95.4 & 4.2 & 0.4 & & \\
\hline \multirow{2}{*}{ AP2* } & \multirow{2}{*}{1.54} & $0.00-0.60$ & 89.3 & 9.8 & 1 & & \multirow{2}{*}{-} \\
\hline & & $0.60-1.54$ & - & 91 & 9 & & \\
\hline \multirow{7}{*}{ AP3* } & \multirow{7}{*}{4.10} & $0.00-0.40$ & 78.3 & 18.8 & 2.8 & & \multirow{7}{*}{ - } \\
\hline & & $0.40-0.60$ & 82.2 & 16.4 & 1.4 & & \\
\hline & & $0.60-0.75$ & 73.7 & 25.2 & 1.1 & & \\
\hline & & $0.75-2.00$ & - & 90 & 10 & & \\
\hline & & $2.00-2.40$ & - & 91 & 9 & & \\
\hline & & $2.40-3.10$ & - & 93 & 7 & & \\
\hline & & $3.10-3.50$ & 89.3 & 8.4 & 2.4 & & \\
\hline
\end{tabular}




\begin{tabular}{|c|c|c|c|c|c|c|c|}
\hline & & $3.50-3.70$ & 79.8 & 18.3 & 1.8 & & \\
\hline & & $3.70-4.10$ & - & 99 & 1 & & \\
\hline \multirow{5}{*}{ AP4* } & \multirow{5}{*}{2.00} & $0.00-0.30$ & 79.1 & 20.3 & 0.6 & & \multirow{5}{*}{ - } \\
\hline & & $0.30-0.50$ & 78.5 & 20.6 & 0.9 & & \\
\hline & & $0.50-0.65$ & 83 & 14.6 & 2.2 & & \\
\hline & & $0.65-1.10$ & - & 96 & 4 & & \\
\hline & & $1.10-2.00$ & - & 97 & 3 & & \\
\hline \multirow{2}{*}{ AP5* } & \multirow{2}{*}{3.20} & $0.00-2.60$ & - & 89 & 11 & & \multirow{2}{*}{ - } \\
\hline & & $2.060-3.20$ & - & 90 & 10 & & \\
\hline \multicolumn{8}{|c|}{ Mellupīte } \\
\hline MG1 & 7.00 & - & - & - & - & \multirow{13}{*}{2.46} & 181.18 \\
\hline MG2 & 4.50 & - & - & - & - & & 181.73 \\
\hline MG3 & 11.00 & - & - & - & - & & 299.26 \\
\hline \multirow{5}{*}{ MP1* } & \multirow{5}{*}{3.90} & $0.00-0.45$ & 59.9 & 28.4 & 12.2 & & \\
\hline & & $0.45-0.65$ & 66.9 & 28.8 & 4.3 & & \\
\hline & & $0.65-1.10$ & - & 82 & 18 & & - \\
\hline & & $1.10-1.90$ & 71.1 & 27.1 & 1.7 & & \\
\hline & & $1.90-3.90$ & - & 82 & 18 & & \\
\hline \multirow{3}{*}{ MP2* } & \multirow{3}{*}{2.60} & $0.00-1.00$ & - & 94 & 6 & & \multirow{3}{*}{-} \\
\hline & & $1.00-2.25$ & - & 91 & 9 & & \\
\hline & & $2.25-2.60$ & - & 93 & 7 & & \\
\hline \multirow{2}{*}{ MP3* } & \multirow{2}{*}{2.00} & $0.00-0.35$ & - & 90 & 10 & & \multirow{2}{*}{-} \\
\hline & & $0.35-2.00$ & - & 80 & 20 & & \\
\hline \multicolumn{8}{|c|}{ Bērze } \\
\hline BG2 & 6.00 & - & - & - & - & \multirow{8}{*}{0.77} & 152.12 \\
\hline BG3 & 8.00 & - & - & - & - & & 84.04 \\
\hline BG4 & 6.00 & - & - & - & - & & 172.68 \\
\hline \multirow{5}{*}{ BP1* } & \multirow{5}{*}{4.15} & $0.00-0.25$ & - & 72 & 28 & & \multirow{5}{*}{-} \\
\hline & & $0.25-0.75$ & - & 52 & 48 & & \\
\hline & & $0.75-1.70$ & - & 57 & 43 & & \\
\hline & & $1.70-3.40$ & - & 86 & 14 & & \\
\hline & & $3.40-4.15$ & - & 87 & 13 & & \\
\hline
\end{tabular}

* The profile bore in territory of the monitoring station

\section{METHODS}

It was already mentioned that fluctuations of the levels of groundwater depend on the rainfall intensity and quantity, air temperature, cumulative evaporation and other factors. The rainfall intensity and air temperature are obtained from direct measurements; hence their impact on fluctuations of the levels of groundwater is mutually comparable [9]. In turn, cumulative evaporation is the value that is calculated indirectly; it can be calculated using various formulas and it depends on several parameters - air temperature, wind velocity, relative humidity etc. [3] and [10].

The methodology applied in the study is based on an empirical study of rainfall intensity and groundwater recharge [11], where the dataset was subdivided into 5-day, 11-day and 13-day periods, depending on the rainfall intensity; the amount of precipitation for the relevant period was summed, and correlation graphs of the amount of precipitation versus changes in the groundwater level during the selected time period were produced. The following conclusion was made as a result of the study: an increase in the groundwater level and its recharge occur, predominantly, when the amount of precipitation exceeds $10 \mathrm{~mm}$ per day [11].

In order to evaluate the impact of rainfall intensity and air temperature on fluctuations of the levels of groundwater, 3 hydrological years from the period of observations $2006-$ 2009 were analysed, using both graphical-analytical and mathematical-statistical methods. A hydrological year starts on October 1 and ends on September 30 the next year. Four seasons of each hydrological year were investigated autumn (September, October, November), winter (December, January, February), spring (March, April, May) and summer (June, July, August). In order to determine the impact of rainfall intensity and air temperature on fluctuations of the levels of groundwater, the obtained data on the levels of groundwater were subdivided into periods of 10 days, i.e. the first period incorporated days from 1 to 10 of each month, days $11-20$ comprised the second 
period and so on. The following parameters were calculated for the selected periods: the change in the levels of groundwater $(\mathrm{cm})$, the total amount of precipitation $(\mathrm{mm})$ and the average air temperature $(0 \mathrm{C})$. The change in the levels of groundwater was determined mathematically, by deducting the initial level for the period from the final level for the period. The obtained value is positive, if the level of groundwater has decreased during the period, or negative, if the level of groundwater has increased. Based on the obtained data, correlation graphs were produced for each month of each hydrological year. Based on the obtained data, an average correlation value for each season for the whole period of observations was determined. The average correlation value demonstrates the dominance of the amount of precipitation or air temperature over fluctuations of the levels of groundwater, i.e. if the obtained correlation value for precipitation is greater than the correlation value for air temperature for the same season, it may be concluded that the impact of the amount of precipitation on fluctuations of the levels of groundwater was greater than that of air temperature for the relevant season.

In order to determine the soil composition and the hydraulic conductivity in the territories of the monitoring stations, an analysis of the grain-size composition was carried out - the sieving method was used for the sandy samples, and the hydrometric analysis - for clayey samples [12]. Based on the obtained results, using a nomograph for the determination of the grain-size composition of topsoil and soil [13], the soil type was determined; loamy sand predominates in Auce, silt loam predominates in Bērze, while sandy loam and silt predominate in Mellupîte; the percentage of sand, silt and clay in the geotechnical boreholes (by layer) was also determined (Table II). To simplify calculations, it was necessary to define constant unified hydraulic conductivity for each soil type using the proportionality principle (hydraulic conductivity for sand vary within 1-100 m/day and those for clay $0.01-0.2 \mathrm{~m} /$ day [7]) for the territories of all 3 monitoring stations: the one adopted for sand was $20 \mathrm{~m} /$ day, for silt $-1 \mathrm{~m} /$ day, and for clay $-0.08 \mathrm{~m} /$ day (selected by the authors).

\section{RESULTS}

The graphic-analytic evaluation has demonstrated that, depending on the air temperature and amount of precipitation, the level of groundwater in the wells decreases or increases. The results of the graphic-analytic evaluation (by season) are summarised in Table III. In the Zemgale region, where the monitoring stations dealt with in the study are situated, the level of groundwater increases during the autumn because of the decrease in the air temperature, while, during the spring, the level of groundwater initially increases due to the rapid melting of the snow cover because of higher air temperature. The level of groundwater decreases later during the spring because the air temperature continues to increase.

TABLE III

RESULTS OF THE GRAPHIC-ANALYTIC EVALUATION

\begin{tabular}{|c|c|c|c|c|c|}
\hline & $\begin{array}{c}\text { Air } \\
\text { temperature }\end{array}$ & $\begin{array}{l}\text { Groundwater level } \\
\text { change in temperature } \\
\text { affects ("+" or "_-") }\end{array}$ & $\begin{array}{l}\text { Precipitation } \\
\text { per day }\end{array}$ & $\begin{array}{l}\text { Groundwater level } \\
\text { change in rainfall } \\
\text { affects ("+" or "_-") }\end{array}$ & $\begin{array}{l}\text { Delay of the } \\
\text { groundwater level } \\
\text { changes, days }\end{array}$ \\
\hline \multicolumn{6}{|c|}{ Autumn } \\
\hline Auce & $0^{0}-+5^{0}$ & $+(0.3-0.4 \mathrm{~m})$ & above $5 \mathrm{~mm}$ & $+(0.05-0.15 \mathrm{~m})$ & delay not observed \\
\hline Bērze & $0^{0}-+5^{0}$ & $+(0.7-0.8 \mathrm{~m})$ & above $5 \mathrm{~mm}$ & $+(0.1-0.2 \mathrm{~m})$ & 2-4 days after rain \\
\hline Mellupīte & $0^{0}-+5^{0}$ & $+(0.6-0.8 \mathrm{~m})$ & above $5 \mathrm{~mm}$ & $+(0.1-0.2 \mathrm{~m})$ & 1-2 days after rain \\
\hline \multicolumn{6}{|c|}{ Winter } \\
\hline Auce & $-10^{0}-0^{0}$ & $-(0.2-0.3 \mathrm{~m})$ & above $5 \mathrm{~mm}$ & effect not observed & delay not observed \\
\hline Bērze & $-10^{0}-0^{0}$ & $-(0.8-1.0 \mathrm{~m})$ & above $5 \mathrm{~mm}$ & effect not observed & 2-4 days after rain \\
\hline Mellupīte & $-10^{0}-0^{0}$ & $-(0.5-0.6 \mathrm{~m})$ & above $5 \mathrm{~mm}$ & effect not observed & 1-2 days after rain \\
\hline \multicolumn{6}{|c|}{ Winter (thaw) } \\
\hline Auce & above $0^{0}$ & $+(0.05-0.1 \mathrm{~m})$ & above $5 \mathrm{~mm}$ & $+(0.05-0.1 \mathrm{~m})$ & delay not observed \\
\hline Bērze & above $0^{0}$ & $+(0.15-0.2 \mathrm{~m})$ & above $5 \mathrm{~mm}$ & $+(0.15-0.2 \mathrm{~m})$ & $\begin{array}{l}2-4 \text { days after the } \\
\text { thaw accession }\end{array}$ \\
\hline Mellupīte & above $0^{0}$ & $+(0.1-0.15 \mathrm{~m})$ & above $5 \mathrm{~mm}$ & $+(0.1-0.15 \mathrm{~m})$ & $\begin{array}{l}\text { 1-2 days after the } \\
\text { thaw accession }\end{array}$ \\
\hline \multicolumn{6}{|c|}{ Spring (flood) } \\
\hline Auce & $0^{0}-+5^{0}$ & $+(0.15-0.25 \mathrm{~m})$ & above $5 \mathrm{~mm}$ & effect not observed & delay not observed \\
\hline Bērze & $0^{0}-+5^{0}$ & $+(0.8-0.9 \mathrm{~m})$ & above $5 \mathrm{~mm}$ & effect not observed & delay not observed \\
\hline Mellupīte & $0^{0}-+5^{0}$ & $+(0.25-0.3 \mathrm{~m})$ & above $5 \mathrm{~mm}$ & $+(0.05-0.1 \mathrm{~m})$ & delay not observed \\
\hline \multicolumn{6}{|c|}{ Spring } \\
\hline Auce & $+5^{0}-+10^{0}$ & $-(0.35-0.5 \mathrm{~m})$ & above $5 \mathrm{~mm}$ & $+(0.05 \mathrm{~m})$ & delay not observed \\
\hline Bērze & $+5^{0}-+10^{0}$ & $-(1.0-1.15 \mathrm{~m})$ & above $5 \mathrm{~mm}$ & effect not observed & delay not observed \\
\hline
\end{tabular}




\begin{tabular}{|c|c|c|c|c|c|}
\hline Mellupīte & $+5^{0}-+10^{0}$ & $-(0.8-0.9 \mathrm{~m})$ & above $5 \mathrm{~mm}$ & effect not observed & delay not observed \\
\hline \multicolumn{7}{|c|}{ Summer } \\
\hline Auce & $+10^{0}-+20^{0}$ & $\begin{array}{c}\text { stable summer water } \\
\text { table }\end{array}$ & above $5 \mathrm{~mm}$ & $+(0.05-0.2 \mathrm{~m})$ & delay not observed \\
\hline Bērze & $+10^{0}-+20^{0}$ & $\begin{array}{c}\text { stable summer water } \\
\text { table }\end{array}$ & above $5 \mathrm{~mm}$ & $+(0.1-0.3 \mathrm{~m})$ & $2-4$ days after rain \\
\hline Mellupīte & $+10^{0}-+20^{0}$ & $\begin{array}{c}\text { stable summer water } \\
\text { table }\end{array}$ & above $5 \mathrm{~mm}$ & $+(0.1-0.3 \mathrm{~m})$ & $1-2$ days after rain \\
\hline
\end{tabular}

"." Groundwater level declining in the well

Groundwater levels depend on the air temperature during the winter season - when the air temperature is negative, the level of groundwater decreases, when the air temperature is positive for a short period of time (a thaw occurs), but the topsoil is still frozen, the level of groundwater increases. Some specialists consider that the frozen topsoil does not filter water, but observations in situ do not support such a point of view. The frozen topsoil layer does not hinder the gravitational water flow. The permeability of the frozen layer is greater, if it has been drier during the freezing [14].

The impact of precipitation is the most evident during the summer and autumn seasons. When the amount of precipitation exceeds $5 \mathrm{~mm}$ per day, an increase in the level of groundwater is observed. After the end of rainfall, the level of groundwater stabilises gradually to the initial level. With the amount of precipitation up to $5 \mathrm{~mm} /$ day, the water retention in topsoils (topsoil humidification, evaporation) and overgrow (transpiration) can reach 57-100\% [15].
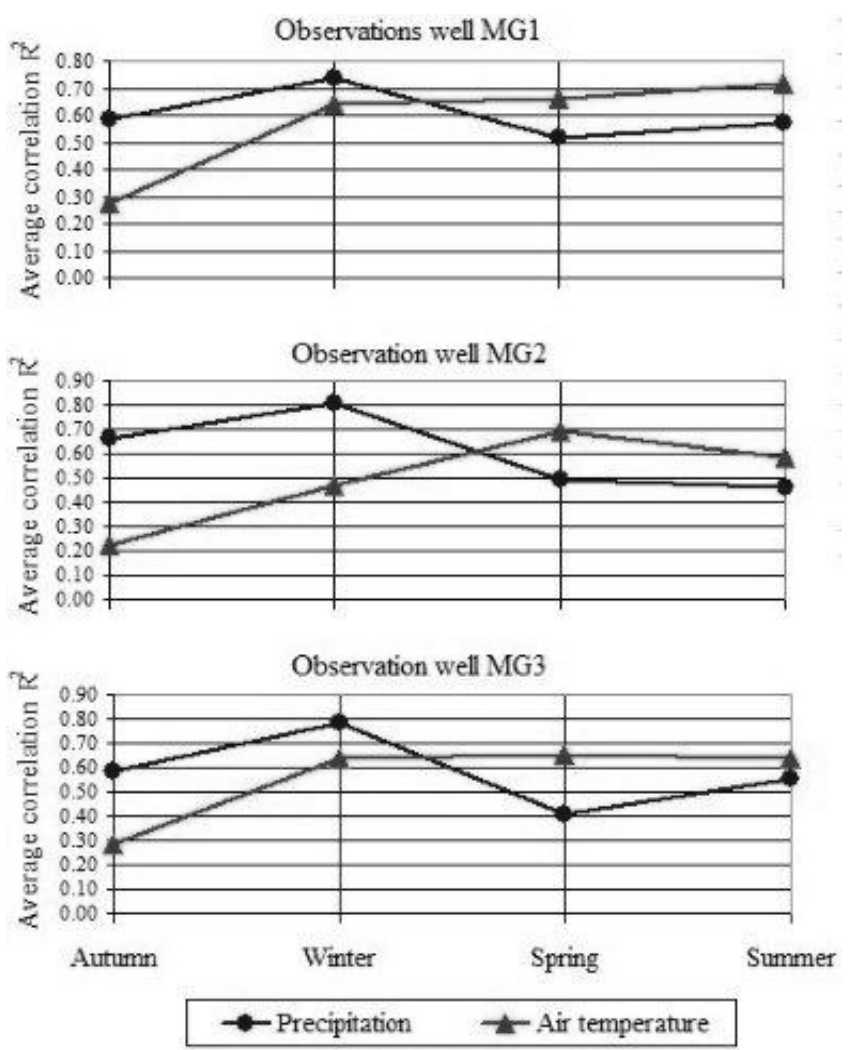

Fig. 2. The average correlation value over the seasons in wells of monitoring station Mellupīte
Evaluating relationships of the totality of samples using the mathematical statistical analysis, the correlation value R2 is determined, which demonstrates how great is the impact of precipitation and air temperature on the levels of groundwater in the wells of the monitoring stations. The results of the analysis are summarized in Table IV. As regards the wells of the Mellupite and Bērze monitoring stations, the impact of precipitation on the levels of groundwater is predominant during the autumn and winter seasons, while, during the spring and summer seasons, the impact of air temperature on the fluctuations of the levels of groundwater is the most important (Fig. 2 and 3). The situation in the Auce monitoring station is different due to the influx of spring water in the wells, which upset normal fluctuations of the levels of groundwater influenced by the amount of precipitation and air temperature (Fig. 4).

TABLE IV

RESULTS OF THE MATHEMATICAL STATISTICS ANALYSIS

\begin{tabular}{|c|c|c|}
\hline & $\begin{array}{l}\text { Correlation of } \\
\text { rainfall to the } \\
\text { groundwater level }\end{array}$ & $\begin{array}{l}\text { Correlation of air } \\
\text { temperature to } \\
\text { groundwater level }\end{array}$ \\
\hline \multicolumn{3}{|c|}{ Mellupīte; borehole MG1 } \\
\hline Autumn & 0.5876 & 0.2735 \\
\hline Winter & 0.7373 & 0.6403 \\
\hline Spring & 0.5162 & 0.6603 \\
\hline Summer & 0.5696 & 0.7159 \\
\hline \multicolumn{3}{|c|}{ Mellupīte; borehole MG2 } \\
\hline Autumn & 0.6589 & 0.2200 \\
\hline Winter & 0.8083 & 0.4658 \\
\hline Spring & 0.4887 & 0.6935 \\
\hline Summer & 0.4652 & 0.5836 \\
\hline \multicolumn{3}{|c|}{ Mellupīte; borehole MG3 } \\
\hline Autumn & 0.5858 & 0.2827 \\
\hline Winter & 0.7827 & 0.6411 \\
\hline Spring & 0.4099 & 0.6555 \\
\hline Summer & 0.5553 & 0.6392 \\
\hline \multicolumn{3}{|c|}{ Auce; borehole AG1 } \\
\hline Autumn & 0.4140 & 0.4464 \\
\hline Winter & 0.6519 & 0.6262 \\
\hline Spring & 0.5024 & 0.7556 \\
\hline Summer & 0.5103 & 0.5696 \\
\hline \multicolumn{3}{|c|}{ Auce; borehole AG2 } \\
\hline Autumn & 0.3252 & 0.1733 \\
\hline Winter & 0.6169 & 0.4579 \\
\hline
\end{tabular}




\begin{tabular}{|c|c|c|}
\hline Spring & 0.6761 & 0.4725 \\
\hline Summer & 0.5077 & 0.4840 \\
\hline \multicolumn{3}{|c|}{ Auce; borehole AG3 } \\
\hline Autumn & 0.4334 & 0.5558 \\
\hline Winter & 0.5348 & 0.3852 \\
\hline Spring & 0.6786 & 0.4593 \\
\hline Summer & 0.4570 & 0.2786 \\
\hline \multicolumn{3}{|c|}{ Bērze; borehole BG2 } \\
\hline Autumn & 0.7084 & 0.4533 \\
\hline Winter & 0.6043 & 0.5059 \\
\hline Spring & 0.3812 & 0.5697 \\
\hline Summer & 0.3993 & 0.8323 \\
\hline \multicolumn{3}{|c|}{ Bērze; borehole BG3 } \\
\hline Autumn & 0.7084 & 0.4533 \\
\hline Winter & 0.6043 & 0.5059 \\
\hline Spring & 0.3014 & 0.3090 \\
\hline Summer & 0.4610 & 0.6616 \\
\hline \multicolumn{3}{|c|}{ Bērze; borehole BG4 } \\
\hline Autumn & 0.7906 & 0.5077 \\
\hline Winter & 0.5560 & 0.6274 \\
\hline Spring & 0.6026 & 0.9971 \\
\hline Summer & 0.5314 & 0.4799 \\
\hline \multicolumn{2}{|c|}{} \\
\hline
\end{tabular}
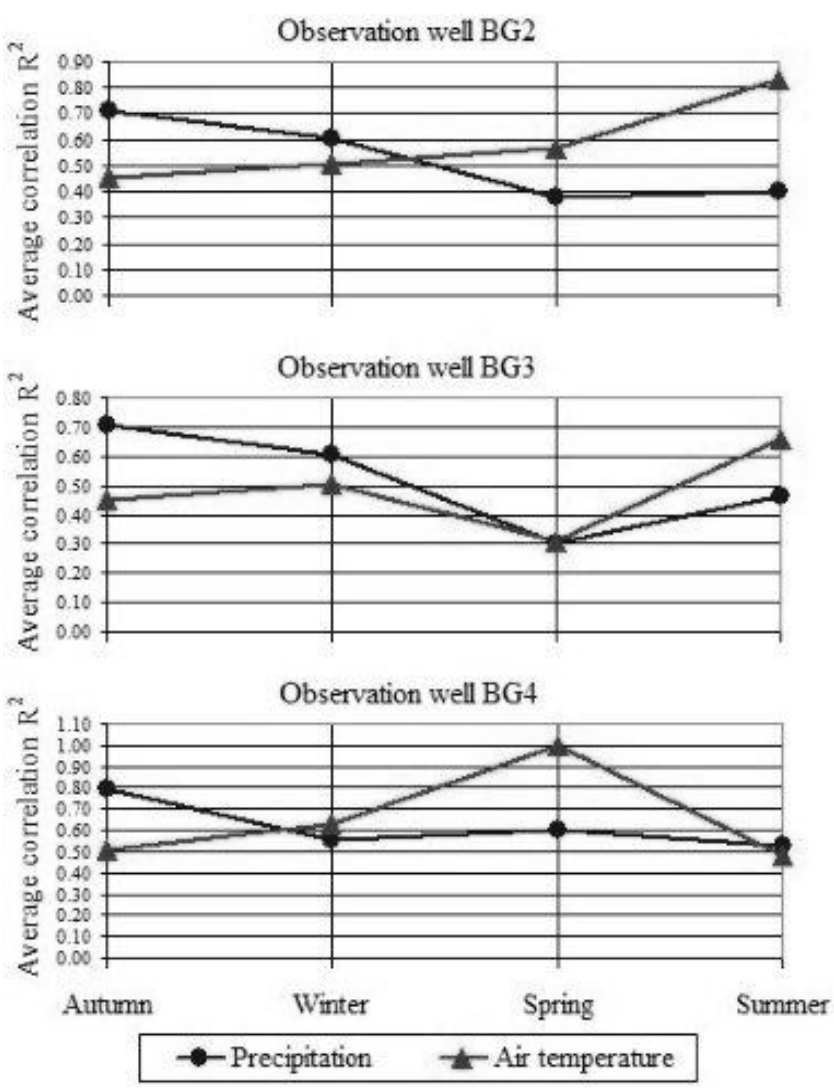

Fig. 3. The average correlation value over the seasons in wells of monitoring station Bērze
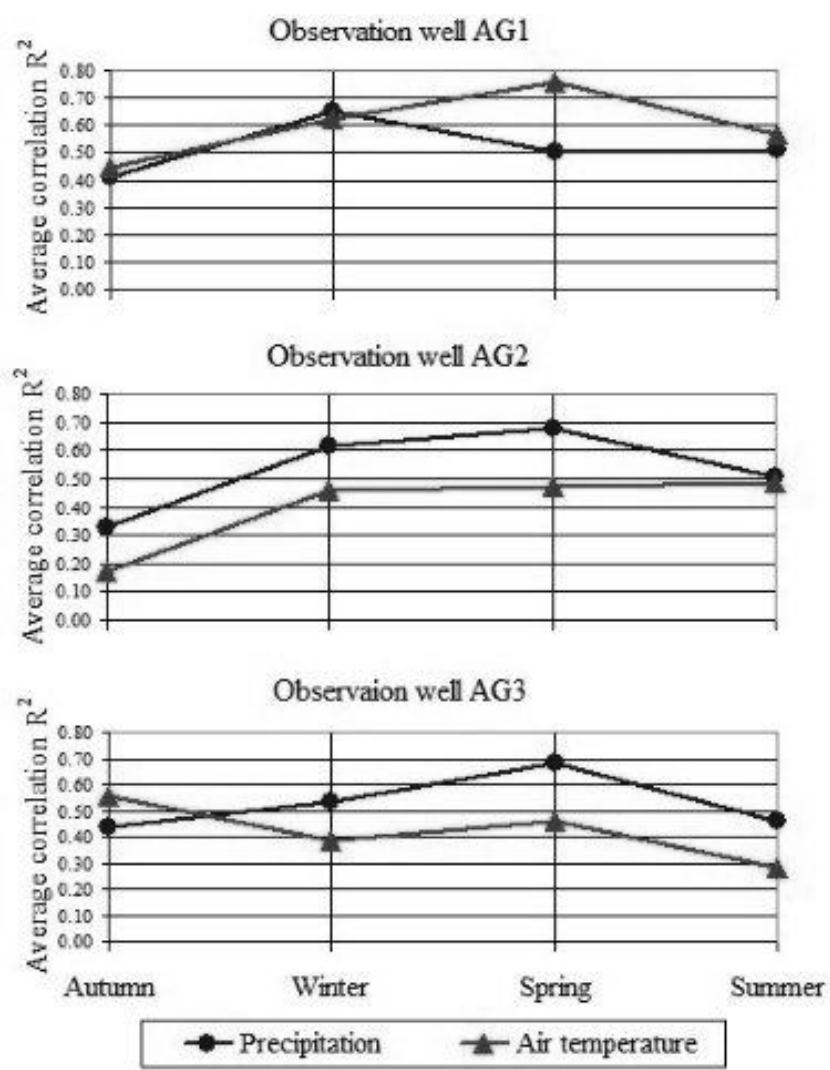

Fig. 4. The average correlation value over the seasons in wells of monitoring station Auce

\section{DISCUSSION}

Evaluating the results from all three monitoring stations obtained using the methods of the graphic-analytic and mathematical statistical analysis, it has been confirmed that the level of groundwater increases during the spring and autumn, and decreases during the winter and, in particular, during the summer [7]. Fluctuations of the level of groundwater during each season are, predominantly, determined by one or the other of the parameters under discussion.

The level of groundwater during the autumn and winter seasons varies under the impact of the amount of precipitation - the level of groundwater increases, if the air temperatures are above zero and the amount of precipitation exceeds $5 \mathrm{~mm}$ per day. A relationship is observed during that period of time that, when the air temperature gradually decreases to $0^{0}$, the level of groundwater increases steadily, due to the fact that, under the influence of low air temperature, rainwater is unable to evaporate completely and penetrates into the groundwater. It is called "the autumn-winter increase", which is influenced by the amount of atmospheric precipitation and its intensity during the autumn and winter seasons, and it ends when a period with negative air temperatures occurs [16]. The amount of precipitation, which is smaller than $5 \mathrm{~mm}$ per day during the autumn season, does not significantly influence fluctuations of the level of groundwater. When the air temperature decreases below $0^{0}$, the level of groundwater decreases as well, but, during the winter season, when a 
thaw and positive air temperatures occur, the level of groundwater tends to increase by $0.2-0.3 \mathrm{~m}$ in Auce, by 0.8 $1.0 \mathrm{~m}$ in Bērze and by $0.5-0.6 \mathrm{~m}$ in Mellupite. As a result of the temperature decrease below $0^{0}$, capillary ascent of groundwater takes place from deeper and warmer layers towards higher layers that are closer to the earth's surface, which explains the decrease of the level of groundwater during the winter [17]. With water moving up, the topsoil pores are filled with water, which then also freezes. This is called "the pre-spring lowering", the duration of which depends on the duration of the period of constant negative air temperatures in connection with the cessation of infiltration in the aeration zone during the freezing period [16].

Within the framework of the Wyoming study, three groundwater recharge episodes were singled out, depending on the depth of a groundwater aquifer/level. Our study corresponds to the part of the above-mentioned study, which characterises high levels of groundwater, and it can be stated that it confirms the conclusions of scientists of the University of Wyoming, i.e. the regime of the top layer of groundwater is closely related to the amount of precipitation. Most of short-term rainfall generates separate processes of recharge of the levels of groundwater, and, depending on the existing depth of the level of groundwater, the level increase episodes for such rainfall are distinguishable from one another [18].

The fluctuations of the level of groundwater during the spring and summer seasons depend on the air temperature. During the spring, with an increase in the air temperature, the level of groundwater increases as well, by $0.15-0.3 \mathrm{~m}$ due to the melting of the snow cover and ice. With the air temperature increasing, the melting starts from the bottom of the frozen topsoil layer, thus increasing the level of groundwater [17]. It is also called "the spring increase", starting from the start of the period of positive air temperature; its duration and size depend on the thickness of snow accumulated during the winter period and intensity of its melting [16]. When the air temperature increases above $+10^{\circ}$, the level of groundwater gradually decreases by $0.35-0.50 \mathrm{~m}$ in Auce, by $1.00-1.15 \mathrm{~m}$ in Bērze and by $0.80-0.90 \mathrm{~m}$ in Mellupite, and the summer levels become stable $-2.00 \mathrm{~m}$ below the earth surface in Mellupite, $2.20 \mathrm{~m}$ below the earth surface in Berrze and $1.50 \mathrm{~m}$ below the earth surface in Auce. During the time period when the level of groundwater steadily decreases, there is no infiltration of rainwater into groundwater, because of the fast evaporation of precipitation under the influence of relatively high air temperatures. The above-mentioned decrease of the level of groundwater is called "the summer-autumn decrease", which is associated with intensive evaporation from the top of groundwater during the vegetation period [16].

It was observed analyzing the data that the impact of the amount of precipitation on the fluctuations of the level of groundwater at the monitoring objects occurs with a time delay, i.e., at the Mellupite monitoring station, the level of groundwater increases 1 - 2 days (Fig. 5) after the amount of precipitation exceeds $5 \mathrm{~mm} /$ day, at the Bērze monitoring station - 2 - 4 days later (Fig. 6), while, at the Auce monitoring station, the level of groundwater increases exactly on the day when the observed amount of precipitation has exceeded 5-10 mm (Fig. 7) (the most characteristic well for each monitoring station is shown in the figures).

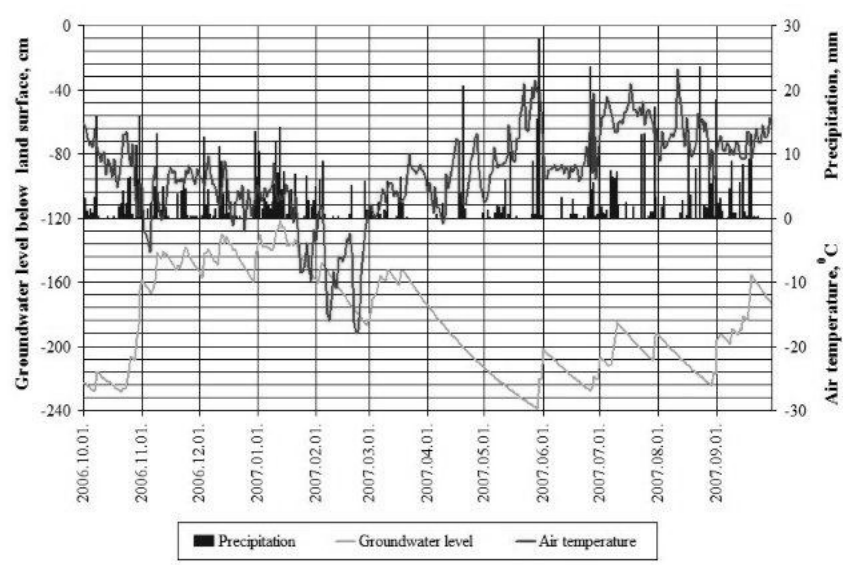

Fig. 5. Observed precipitation, air temperature and groundwater level in the borehole MG1 (2006 - 2007 hydrological year)

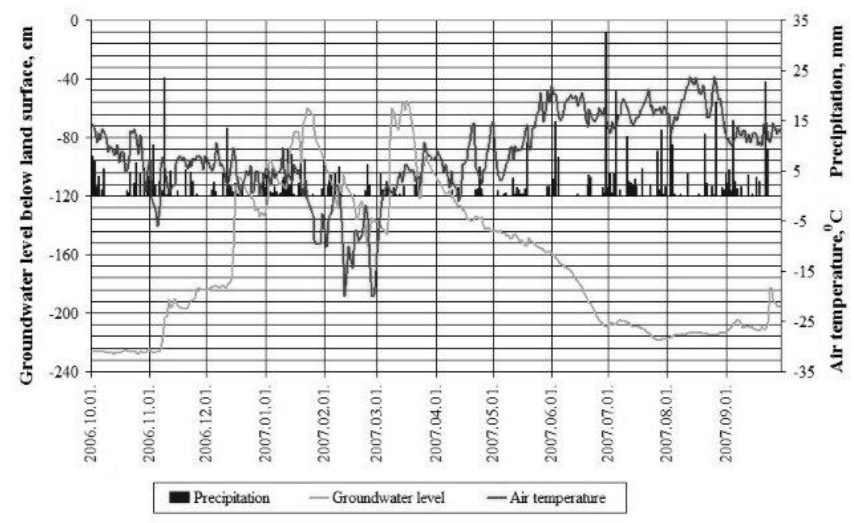

Fig. 6. Observed precipitation, air temperature and groundwater level in the borehole BG3 (2006 - 2007 hydrological year)

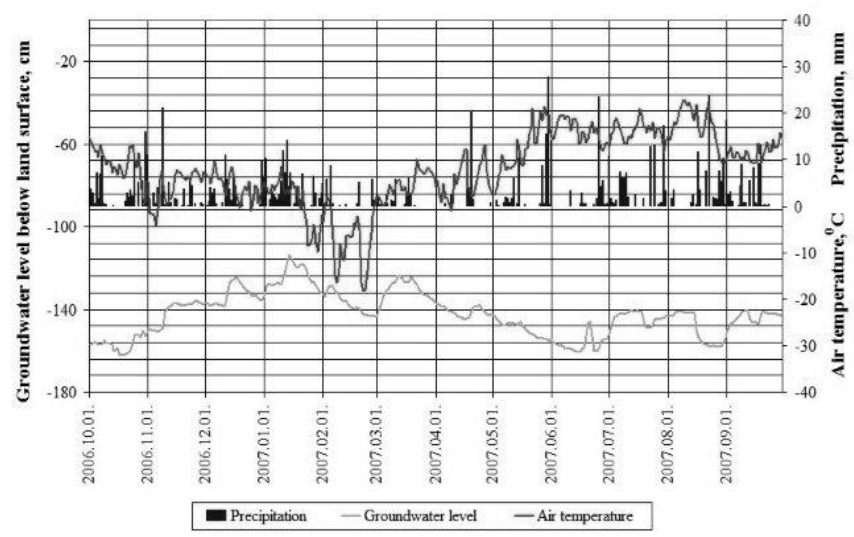

Fig. 7. Observed precipitation, air temperature and groundwater level in the borehole AG1 (2006 - 2007 hydrological year)

If the amount of precipitation is smaller, no increase of the levels of groundwater is observed in the wells of the 
monitoring stations. That is explained by different grainsize composition of soils at those monitoring stations and the average depth of the levels of groundwater.

The shallowest groundwater table is at Auce. The average level of groundwater there was $0.72-1.41 \mathrm{~m}$ below the earth surface during the period of observations, depending on the well. Loamy sand predominates in the area, with the hydraulic conductivity $\mathrm{k}=7.69 \mathrm{~m} / \mathrm{day}$, which ensures that the precipitation that has failed to evaporate infiltrates in the soil and influences the level of groundwater on the same day when the amount of precipitation exceeds $5 \mathrm{~mm}$, increasing it. The average levels of groundwater at the Mellupite monitoring station are the deepest for the areas under discussion $(1.81-2.99 \mathrm{~m}$ below the earth surface, depending on the well). Sandy loam and silt soils with the hydraulic conductivity $\mathrm{k}=2.46 \mathrm{~m} / \mathrm{day}$ are predominant there, which ensures that the precipitation that has failed to evaporate infiltrates in the soil and increases the level of groundwater with an average delay of 1 to 2 days. In turn, studying the Bērze monitoring station, we can see that the prevailing silt loam soils have a very low hydraulic conductivity $\mathrm{k}=0.77 \mathrm{~m} /$ day, while the average level of groundwater is $0.84-1.73 \mathrm{~m}$ below the earth surface, which is the reason why the level of groundwater increases 2 to 4 days after the amount of precipitation exceeds $5 \mathrm{~mm} /$ day (Table II).

\section{CONCLUSIONS}

As a result of the study, the predominant impact of meteorological conditions (air temperature and amount of precipitation) on the fluctuations of the level of groundwater by the season has been proven, using the graphic-analytical method and the method of mathematical statistical analysis. It is possible to utilise the methodology utilised during the study for the analysis of levels of groundwater depending on the amount of precipitation and air temperature.

At the Mellupite and Bērze monitoring stations, during the autumn (Sepember, October, November) and winter (December, January, February) seasons, the impact of the amount of precipitation on the fluctuations of the level of groundwater is predominant. That is observed during the periods, when the air temperature varies from $0^{0}$ to $+10^{0}$, and the amount of precipitation exceeds 5-10 mm per day.

In turn, during the spring (March, April, May) and summer (June, July, August) seasons, the level fluctuations depend on the average air temperatures, if they vary from $0^{0}$ to $+10^{0}$.

When the air temperature is from $0^{0}$ to $+10^{0}$, the levels of groundwater increase, but, when the air temperature decreases $\left(0^{0}\right.$ to $\left.-10^{0}\right)$, the level of groundwater decreases as well. If the air temperature is above $+10^{\circ}$ or below $-10^{\circ}$, the levels of groundwater stabilise at the level below the earth surface, which is characteristic for summer or winter, correspondingly.

The correlation of the air temperature amount of precipitation with the levels of groundwater for the wells of the Auce monitoring stations is not as good as that observed in the wells of the Bērze and Mellupite monitoring stations. That is explained by the influx of spring water in the wells of the Auce monitoring station, which distorts normal fluctuations of the level of groundwater under the influence of the amount of precipitation and air temperature.

The delay of the impact of precipitation is most evident in the areas with a low soil hydraulic conductivity, i.e. the lower the hydraulic conductivity, the later fluctuations of the level of groundwater are observed after rainfall, with the same levels.

\section{ACKNOWLEDGMENT}

This study has supported by the European Social Fund within the framework of the project "Establishment of interdisciplinary scientists group and modeling system for groundwater research".

\section{REFERENCES}

1. Ruosteenoja, K., Carter, T. R., Jylhä, K., Tuomenvirta, H. Future climate in world regions: an intercomparison of model-based projections for the new IPCC emissions scenarios. The Finnish Environment, Helsinki, 2003. 83 p.

2. Lagzdinšs, A., Jansons, V., Abramenko, K. Ūdeņu kvalitātes standarta noteikšana pēc biogēno elementu koncentrācijas notecē no lauksaimniecībā izmantotajām platībām. Latvijas Lauksiamniecības univeritātes Raksti, 2008, vol. 21, No. 315, p. 96-105.

3. Krams M., Zīverts, A. Experiments of Conceptual Mathematical Groundwater Dynamics and Runoff Modelling in Latvia. Nordic Hydrology, 1993, vol. 2, No. 24, p. 243-262.

4. Levina, N., Levins, I. Gavena, I. Latvijas pazemes ūdeņu resursi. Dzilna, I. (red.), Valsts Ģeologijas Dienests, Rīga, 1998. 24 lpp.

5. Sophocleous, M. (2004) Groundwater recharge. In: Groundwater [Online]. Eds. Silveira, L., Wohnlich, S., Usunoff, E.J. Encyclopedia of Life Support Systems, Vol. 1, Oxford - [Accessed 12.03.2012.]. Available:

http://www.eolss.net/ebooks/Sample\%20Chapters/C07/E2-09-0105.pdf

6. Vircavs, V., Jansons, V., Kḷavin̦š, U. Gruntsūdeņu veidošanās likumsakarības lauksaimniecībā izmantojamās platībās. Latvijas Universitātes 67. Zinātniskās konferences "Klimata mainība un ūdeņi” rakstu krājums, 2009, p. 101-102.

7. Zīverts, A. Pazemes ūdeņu hidrologija. Latvijas Lauksaimniecības universitāte, Jelgava, 2001. $81 \mathrm{lpp}$.

8. Levina, N., Levins, I., Gaile, R., Cīrulis, A. Valsts pazemes ūdeņu monitorings, 2000. gads. Valsts geologijas dienests, Rīga, 2001. 31 lpp.

9. Okkonen J., Jyrkama M., Kløve B. A conceptual approach for assessing the impact of climate change on groundwater and related surface waters in cold regions (Finland). Hydrogeology Journal, 2010, vol. 18, p. 429-439.

10. Mészároš, I., Miklánek, P. Calculation of potential evapotranspiration based on solar radiation income modeling in mountainous areas. Biologia, Bratislava, 2006, vol. 61, p. 284 - 288.

11. Owor, M., Taylor, R. G., Tindimugaya, C., Mwesigwa, D. Rainfall intensity and groundwater recharge: empirical evidence from the Upper Nile Basin. Environmental Research Letters, 2009, vol. 4, p. 192-198.

12. Ломтадзе, В. Методы лаборатоных исследований физико механических свойств горных пород. Издательство "недра". Ленинградское отделение, 1972. 312 стр.

13. Ministru kabineta noteikumi Nr.804 Noteikumi par augsnes un grunts kvalitātes normatīviem, spēkā no 2005.gada 25.oktobra.

14. Șksiṇķisis, C. Augšņu drenēšana. Izdevniecība Avots, Rīga, 1986. 331 lpp.

15. Sarma, B. Upju hidrologija: noteces un hidrometrijas pamati. Latvijas valsts izdevniecība, Rīga, 1960. 203 lpp. 
16. Levina, N., Levins, I. Pazemes ūdeņu pamatmonitorings, 2004. gads. Latvijas vides, geologijas un meteorologijas ağentūra, Rīga, 2005. 42 lpp.

17. Schneider, R. Correlation of groundwater levels and air temperatures in the winter and spring in Minnesota. Minnesota Division of Waters, 1961, vol. 1, p. 219-228.

18. Wu, J., Zhang, R. Analysis of rainfall-infiltration recharge to groundwater. In: Proceedings of Fourteenth Annual American Geophysical Union: Hydrology Days. Ed. Morel-Seytoux H. J. Colorado state university, Colorado, 1994. p. 420-430.

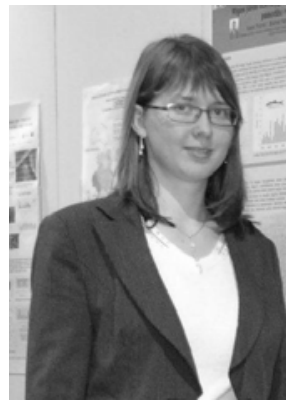

Ilva Vitola, Mg.sc.ing., Laboratory assistant, Department of Environmental Engineering and Water Management, Latvia University of Agriculture (LLU). Master of engineering in hydroengineering LUA, 2012. Master thesis "The analysis of installation options for environmentally - friendly hydropower stations without the dam on rivers in Latvia". Research interests: groundwater seasonal fluctuations.

Address: Akademijas Street 19, LV-3001, Jelgava, Latvia Phone: +371 26106071

E-mail: ilva.anisimova@gmail.com

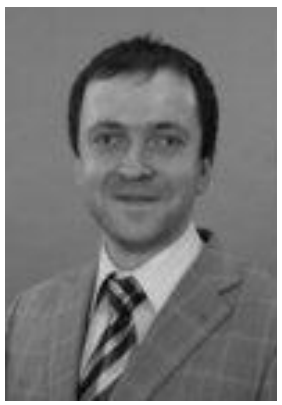

Valdis Vircavs, Mg.sc.geol. is a lecturer in Latvia University of Agriculture, Faculty of Rural Engineering, Department of Environmental Engineering and Water Management, second year PhD student and scientific researcher in ESF project.

$\mathrm{He}$ was involved in international and national projects: EU Co-financed BONUS program RECOCA, National research program 7/06VP8., LLU (Latvia University of Agriculture) ZP 07-78 and from 2009-2012. 2009/0212/1DP/1.1.1.2.0/09/APIA/VIAA/060E F7 "Establishment of interdisciplinary scientist group and modelling system for groundwater research".

Scientific field of interests are groundwater quality and quantity, regime of groundwater table, interaction between stream water, drainage and groundwater.

Phone: +371 63029908; +371 29418944

E-mail: valdis.vircavs@llu.lv

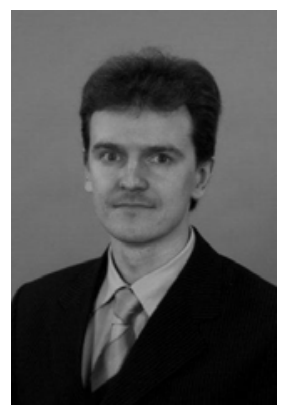

Kaspars Abramenko, Mg.sc.ing, lecturer, Faculty of Rural Engineering, Latvia University of Agriculture. Since 2000 he is among the academic staff in the department of Environmental Engineering and Water Management. In 2002 he graduated MSc studies on Environmental Engineering Science.

Experience of 13 years research in agricultural impact assessment on water bodies and water quality modeling is connected to his $\mathrm{PhD}$ thesis "Agricultural diffuse source pollution in Latvia". He mainly deals with multi scale agricultural run-off monitoring data collection in Latvia to estimate pollution source apportionment within rive basins. As a scientist he is involved in national water monitoring programmes and international research projects BEAROP, BSRP, COST, RECOCA concerning nutrient losses from agricultural land. Since 2010 he participates in the ESF project „Establishment of interdisciplinary scientist group and modeling system for groundwater research".

Phone: +371 63029908

E-mail: kaspars.abramenko@1lu.lv

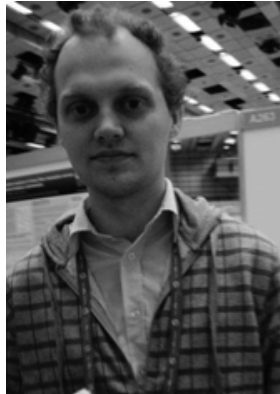

Didzis Lauva, Mg.sc., Researcher and independent consultant, Faculty of Rural Engineering, Latvia University of Agriculture since 2010. Has two masters degrees; in physics, focusing on vision science (2008, Faculty of Physics and Mathematics, University of Latvia) and in geography (2011, Faculty of Geography and Earth Sciences, University of Latvia).

Previous work experience covers wide subjects where critical analythics, programming, planning, management and decision making were necessary; has worked as assistant in Institute of Solid State Physics, previously as engineer and dispatcher in public transport company "Rigas Satiksme".

Current work assignments includes groundwater regime and time series analysis with focus on programming and modelling, geoinformatics and data analysis.

Member of European Geosciences Union (EGU).

Phone: +371 29945987

E-mail: didzis@lauvadidzis.com

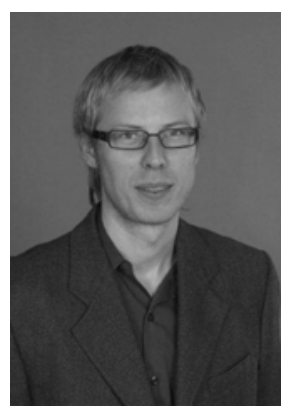

Arturs Veinbergs, Mg.sc.ing., Assistant, Department of Environmental Engineering and Water Management, Latvia University of Agriculture (LLU). Master of engineering in environmental engineering LUA, 2012. Master thesis "Influence of Groundwater Fluctuations on Nitrate Nitrogen Runoff in Open Channels". Publications: author/co-author of 9 scientific papers. Research interests: water quality modelling, groundwater monitoring in Latvia. Address: 19 Akademijas street, LV-3001, Jelgava, Latvia

E-mail: arturs.veinbergs@1lu.1v
Phone: +37163029908 